CATALLAXY

Volume 5 Issue 1 June 2020

e-ISSN 2544-090X

¿ www.catallaxy.pl

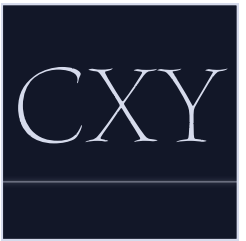

Oryginalny artykut naukowy

otrzymano: 22.04.2020 / zaakceptowano: 15.07.2020 / opublikowano online: 21.07.2020

Gers, O. (2020). Porównanie wsparcia dla Polski od Unii Europejskiej w ramach finansowania 2007-2013 i 2014-2020. Catallaxy, 5(1): 5-12. doi:10.24136/cxy.2020.001.

\title{
Porównanie wsparcia dla Polski od Unii Europejskiej w ramach finansowania 2007-2013 i 2014-2020
}

\section{OLGA GERS}

Uniwersytet Warminsko-Mazurski w Olsztynie, Wydział Nauk Ekonomicznych, ul. Oczapowskiego 4, 10-719 Olsztyn, Polska Dolga.gers@student.uwm.edu.pl

(iD) orcid.org/0000-0001-5919-9526

\section{Abstrakt}

Motywacja: W literaturze przedmiotu można odnaleźć wiele informacji o dofinansowaniu, jakie Polska uzyskuje od Unii Europejskiej (UE). Brakuje jednak wskazania różnic między perspektywą finansową a budżetem oraz porównania wsparcia dla Polski w ramach różnych perspektyw finansowych. Tę lukę występującą w literaturze przedmiotu próbuje się wypełnić w ramach niniejszego artykułu.

Cel: Celem artykułu jest wskazanie różnic między perspektywą finansową a budżetem oraz sprawdzenie czy wsparcie finansowe dla Polski od UE zwiększa się, porównując kolejne perspektywy finansowe.

Materiały i metody: W artykule wykorzystano literaturę przedmiotu, informacje statystyki publicznej oraz narzędzia analizy porównawczej.

Wyniki: Niektóre programy krajowe przeformowaly się w perspektywie 2014-2020, lecz nie uległy zmianie ich priorytety. Poziom wsparcia unijnego dla Polski oraz poszczególnych województw tego państwa zwiększył się w kolejnej perspektywie, jednak nie jest to jednoznaczne z automatycznym wzrostem wsparcia w każdym okresie finansowania.

Stowa kluczowe: perspektywa finansowa; Unia Europejska; Polska; budżet

JEL: F02; O52; G28; R58

\section{Wprowadzenie}

Działania Unii Europejskiej (UE) kojarzone są m.in. $z$ funduszami dotacyjnymi, które towarzyszą jej od 1 listopada 1993 roku, tj. od wejścia w życie Traktatu z Maastricht. Trzeba jednak mieć świadomość, że fundusze europejskie są znacznie starsze, np. Europejski Fundusz Społeczny powstał w 1960 roku, a Europejski Fundusz Orientacji i Gwarancji Rolnych w 1964 roku. Po nich powstawały jeszcze kolejne (Perkowski, 2013, s. 201).
W 2004 roku Polska, po 10 latach starań, dołączyła do UE (Kabat i Rudnicki, 2009, s. 297), co miało miejsce $w$ trakcie perspektywy finansowej 2000-2006. Już od pierwszego roku członkostwa i do końca trwania tej perspektywy objęto ją pomocą finansową UE w ramach różnych programów. Kolejne wsparcie było wpisane $w$ ramy finansowania 2007-2013, a później - w lata 2014-2020 (Musiałkowska, 2009, s. 223). Następna perspektywa planowana jest na lata 2021-2027.

Celem artykułu jest wskazanie różnic między perspektywą finansową a budżetem 
oraz sprawdzenie czy wsparcie finansowe dla Polski od UE zwiększa się, porównując kolejne perspektywy finansowe.

W sekcji 2. dokonano przeglądu literatury podmiotu. W sekcji 3. opisano wykorzystane materiały i metody. W sekcji 4. przedstawiono otrzymane wyniki, natomiast w sekcji 5. zawarto podsumowanie przeprowadzonej analizy.

\section{Przegląd literatury}

W literaturze można znaleźć m.in. porównanie perspektywy finansowej $z$ budżetem, czego dokonała przykładowo Oręziak (2009). Uznała ona m.in., że perspektywy finansowej nie można traktować jako zwykłego programu, ponieważ założone $\mathrm{w}$ niej progi wydatków mają charakter wiążący z punktu widzenia instytucji, które uczestniczą $\mathrm{w}$ procedurze budżetowej.

Pespektywa finansowa jest dokumentem, w którym zawarte są ogólne ramy, w jakich powinien znajdować się budżet na dany rok. Jest on następstwem planowania średnioterminowego, które ma podstawowe znaczenie w zarządzaniu finansami UE. Obejmuje ona kilka lat i pełni ważną rolę przy ustalaniu budżetu (Oręziak 2009, s. 118).

W artykule 312 Traktatu o Funkcjonowaniu Unii Europejskiej perspektywa finansowa obejmuje co najmniej 5 lat. Od 1993 roku jest to 7 lat. Jej uchwalenie zajmuje około 2 lata. Perspektywa finansowa jest decyzją wszystkich państw unijnych, których dotyczy finansowanie tej organizacji. Wydatki są podzielone na grupy, które są odwzorowaniem obecnych ambicji politycznych UE $w$ danych latach (Małuszyńska, 2018, s. 106).

Perspektywy finansowej nie można uznawać za kilkuletni budżet, gdyż coroczne uchwalanie budżetu ma duże znaczenie dla bieżącego kreowania dochodów i wydatków budżetowych na dany rok. Największa różnica polega na tym, że w perspektywie finansowej limity są podane $\mathrm{w}$ odniesieniu do głównych grup wydatków, a natomiast w budżecie wydatki muszą być podane szczegółowo. Instytucje, które uczestniczą w procedurze bu- dżetowej mają swobodę, jeśli chodzi o kształtowanie wysokości wydatków w ramach poszczególnych grup (Oręziak, 2009, s. 134).

Budzet UE jest rozkładem wszystkich dochodów i wydatków unijnych w ciągu jednego roku kalendarzowego, tj. od 1 stycznia do 31 grudnia. Ten plan finansowy nie może być większy niż 1,23\% dochodu narodowego brutto (DNB) wszystkich państw członkowskich. W praktyce stanowi około 1,00\% DNB. $Z$ tego budżetu są finansowane m.in. wszystkie działania podejmowane przez UE, tj:: administracja, polityki i programy pomocowe (Janiak, 2015, s. 2).

Na początku każda ze wspólnot europejskich (tj. Europejska Wspólnota Gospodarcza, Europejska Wspólnota Energii Atomowej oraz Europejska Wspólnota Węgla i Stali) miała swój oddzielny budżet. W 1967 roku, przez stworzenie wspólnych instytucji dla wszystkich tych grup, utworzono jednolity plan finansowy. Wprowadzono w ten sposób budżet ogólny, który tworzono ze składek członkowskich. W 1971 roku, aby sfinansować budżet, wprowadzono system zasobów własnych Wspólnot. Jednym z takim zasobów były tradycyjne zasoby własne (traditional own resources). Składały się one z opłat rolnych i ceł. W 1979 roku dodano do tego zasobu składnik, który opierał się na małej części przychodów z podatku od towarów i usług (value-added tax, VAT) państw członkowskich. W 1988 roku wprowadzono tzw. Pakiet Delorsa, który stanowił największą reformę planu finansowego polegającą na wprowadzeniu limitów zasobów własnych i perspektyw finansowych z limitami wydatków w poszczególnych kategoriach. Wprowadzono również następny instrument, który stanowił źródło dochodu, tj. wpłaty narodowe oparte na udziale państw członkowskich $\mathrm{w}$ produkcie narodowym brutto (PNB) Wspólnot. Następnie zamieniono tę podstawę na DNB (Janiak, 2015, s. 2).

Perspektywy finansowe zawierają następujące programy operacyjne:

- Infrastruktura i Środowisko;

- Innowacyjna Gospodarka (dawniej: Inteligentny Rozwój oraz Polska Cyfrowa); 
- Kapitał Ludzki (dawniej: Wiedza Edukacja Rozwój);

- Pomoc Techniczna;

- Rozwój Polski Wschodniej (dawniej: Polska Wschodnia);

- szesnaście Regionalnych Programów Operacyjnych.

Program Infrastruktura i Środowisko istniał zarówno $\mathrm{w}$ perspektywie finansowej 2007-2013, jak i 2014-2020. Podstawowymi jego celami jest m.in. rozwój infrastruktury technicznej przy jednoczesnej ochronie i poprawie stanu zdrowia ludności, środowiska, rozwijaniu tożsamości kulturowej lub spójności terytorialnej (Szymańska, 2008, s. 73).

Program operacyjny Innowacyjna Gospodarka $z$ perspektywy finansowej 20072013 zastąpił w perspektywie finansowej 2014-2020 program Inteligentny Rozwój oraz Polska Cyfrowa. Priorytet tego programu to wspieranie innowacyjności i konkurencyjności polskiej gospodarki, które wyraża się głównie w zwiększeniu nakładów na badania i rozwój (Tomaszkiewicz, 2014, ss. 136-137).

Program Kapitał Ludzki, który istniał w perspektywie finansowej 2007-2013 zastąpiono w perspektywie 2014-2020 programem Wiedza Edukacja Rozwój. Priorytetem tego programu jest przede wszystkim: wsparcie zawodowe osób poniżej 30. roku życia, którzy mają trudności ze znalezieniem pracy, rozwój innowacji społecznych, mobilności i współpracy ponadnarodowej. Ponadto ważne jest wsparcie reform polityk publicznych $\mathrm{w}$ obszarach zdrowia, zatrudnienia, włączenia społecznego, edukacji, dobrego rządzenia czy szkolnictwa wyższego (Portal Funduszy Europejskich, 2020).

Program Pomoc Techniczna istniał w obu omawianych perspektywach. Jego podstawowym celem jest stworzenie warunków do zwiększania konkurencyjności gospodarki, która jest oparta na wiedzy i przedsiębiorczości. Zapewnia ona wzrost spójności gospodarczej, społecznej i przestrzennej czy zatrudnienia (Tkaczyński i in., 2008, s. 491).

Program Rozwój Polski Wschodniej z perspektywy 2007-2013 zastąpiono programem Polska Wschodnia. Jako priorytet programu uznano wzrost tempa rozwoju społeczno-gospodarczego wschodnich terenów Polski przy uwzględnieniu zasady zrównoważonego rozwoju (Tkaczyński i in., 2008, s. 487).

Szesnaście Regionalnych Programów Operacyjnych istnieje bez zmian od perspektywy finansowej 2007-2013. Umożliwiają one wsparcie finansowe dla danego województwa na działania tam podejmowane. Priorytety i cel programu są ustalane przez każde województwo $z$ osobna, jednak najczęstsze cele to: pozyskiwanie środków na m.in. działania zdrowotne, edukacyjne, promocję regionu, turystykę czy rozwój miast $\mathrm{w}$ regionie i wsparcie dla przedsiębiorców w danym województwie (Zdanukiewicz, 2012, s. 141).

\section{Materiały i metody}

W celu przedstawienia różnic między perspektywą finansową a budżetem wykorzystano literaturę przedmiotu. Omówienie krajowych i regionalnych programów, które istniały $w$ perspektywie 2007-2013 oraz 2014-2020 było możliwe dzięki zastosowaniu analizy opisowej i porównawczej. Porównano również skalę pomocy uzyskanej przez Polskę $\mathrm{w}$ ramach różnych programów i perspektyw finansowych, również w przekrojach województw w ramach programów regionalnych. Materiał empiryczny stanowily statystyki publiczne.

\section{Wyniki badania}

\subsection{Porównanie krajowych i regionalnych programów oraz dofinansowania z UE w perspektywach na lata 2007-2013 i 2014-2020}

W perspektywie finansowej na lata 20072013 największą pomoc finansową odnotowano $\mathrm{w}$ przypadku programu Infrastruktura i Środowisko, natomiast w perspektywie 2014-2020 było to szesnaście Regionalnych Programów Operacyjnych (tabela 1.). Najmniejsze dofinansowanie $w$ perspektywie 
2007-2013 oraz 2014-2020 przeznaczono na program Pomoc Techniczna.

Poziom pomocy finansowej dla programu Infrastruktura i Środowisko $\mathrm{w}$ perspektywie 2014-2020 zmalał o ok. 0,9 mld euro (3\%) w porównaniu z perspektywą na 2007-2013. Program Innowacyjna Gospodarka z perspektywy 2007-2013 podzielono w kolejnej perspektywie na dwa programy - Inteligentny Rozwój oraz Polska Cyfrowa. Łączne dofinansowanie tych dwóch programów wzrosło o 2,1 mld euro (24\%) w porównaniu $z$ programem $z$ poprzedniej perspektywy finansowej. Poziom pomocy unijnej dla programu Wiedza Edukacja Rozwój w perspektywie 2014-2020 zmalał o 5,3 mld euro (53\%) w porównaniu z programem Kapitał Ludzki z perspektywy 2007-2013. Dofinansowanie dla programu Pomoc Techniczna wzrosło $\mathrm{w}$ perspektywie 2014-2020 o 0,2 mld euro (40\%) w porównaniu $z$ poprzednią perspektywą finansową. Poziom pomocy finansowej dla programu Polska Wschodnia ograniczono o 0,4 mld euro (17\%) w porównaniu z programem Rozwój Polski Wschodniej z poprzedniej perspektywy finansowej. Dofinansowanie dla szesnastu Regionalnych Programów Operacyjnych wzrosło aż o 13,9 mld euro (80\%) w perspektywie 2014-2020 w porównaniu $z$ perspektywą 2007-2013.

Porównując perspektywę finansową 2007-2013 oraz 2014-2020 można stwierdzić, że pomoc finansowa od UE dla programów krajowych i regionalnych wzrosła łącznie o 9,55 mld euro, tj. o $14 \%$.

\subsection{Porównanie pomocy finansowej z UE dla województw w ramach szesnastu Regionalnych Programów Operacyjnych w perspektywach na lata 2007-2013 i 2014-2020}

W perspektywie finansowej 2007-2013 największą pomoc unijną $w$ ramach szesnastu Regionalnych Programów Operacyjnych dostało województwo śląskie, natomiast najmniejszą województwo opolskie (tabela 2.). W perspektywie 2014-2020 największe dofinansowanie również dostało województwo śląskie, a najmniejsze województwo lubuskie oraz ponownie województwo opolskie.

Poziom pomocy unijnej dla województwa dolnośląskiego ograniczono $\mathrm{w}$ perspektywie 2014-2020 o 1,01 mld euro (81\%) w porównaniu $z$ perspektywą 2007-2013. Dofinansowanie dla województwa kujawsko-pomorskiego wzrosło o 0,95 mld euro (100\%) w porównaniu perspektywy 2014-2020 do perspektywy 2007-2013. Poziom wsparcia finansowego od UE dla województwa lubelskiego wzrósł o 1,07 mld euro (92\%) w porównaniu obecnej perspektywy do poprzedniej. Dofinansowanie dla województwa lubuskiego w perspektywie 2014-2020 wzrosło o 0,46 mld euro (104\%) w porównaniu $z$ poprzednią perspektywą finansową. Poziom pomocy finansowej od UE $w$ perspektywie finansowej 2014-2020 dla województwa łódzkiego wzrósł o 1,24 mld euro (123\%) w porównaniu $z$ poprzednią perspektywą. Poziom wsparcia dla województwa małopolskiego w obecnej perspektywie wzrósł o 1,58 mld euro (122\%) $\mathrm{w}$ porównaniu $z$ poprzednią perspektywą. Województwo mazowieckie otrzymało o 0,25 mld euro (114\%) więcej w obecnej perspektywie, niż w poprzedniej. Poziom pomocy finansowej od UE dla województwa opolskiego wzrósł o 0,47 mld euro (109\%) w perspektywie 2014-2020 w porównaniu do perspektywy 2007-2013. Dofinansowanie dla województwa podkarpackiego $\mathrm{w}$ perspektywie finansowej 2014-2020 wzrosło o 0,97 mld euro (86\%) w porównaniu z poprzednią perspektywą. Województwo podlaskie otrzymało o 0,57 mld euro (89\%) więcej w perspektywie 2014-2020, niż w latach 2007-2013. Natomiast województwo pomorskie otrzymało o 0,97 mld euro (109\%) więcej w obecnej perspektywie finansowej, niż w poprzedniej. Poziom pomocy finansowej dla województwa śląskiego w perspektywie 2014-2020 wzrósł o 1,76 mld euro (103\%) w porównaniu z perspektywą 2007-2013. Województwo świętokrzyskie otrzymało od UE o 0,63 mld euro (86\%) więcej w perspektywie 2014-2020, niż w poprzedniej perspektywie. Dofinansowanie dla województwa warmińsko-mazurskiego było większe o 0,69 mld euro (67\%) w per- 
spektywie 2014-2020, niż w perspektywie 2007-2013. Województwo wielkopolskie otrzymało pomoc o 1,18 mld euro (93\%) większą w perspektywie finansowej 2014-2020, niż $\mathrm{w}$ poprzedniej perspektywie. Natomiast województwo zachodniopomorskie mogło liczyć na pomoc o 0,76 mld euro (90\%) większą w perspektywie finansowej 2014-2020, niż w perspektywie 2007-2013.

Jak można zauważyć, wsparcie finansowe UE dla wszystkich szesnastu województw w ramach Regionalnych Programów Operacyjnych wyraźnie wzrosło.

\subsection{Perspektywa finansowa 2021-2027}

W 2021 roku rozpoczyna się kolejna siedmioletnia perspektywa finansowa. $\mathrm{Na}$ podstawie projektu rozporządzenia ogólnego z 29 maja 2018 roku, Polska w ramach Polityki Spójności otrzyma $64397 \mathrm{mln}$ euro, czyli ponad 291042 mln złotych (1 euro jest równe ok. 4,52 złotych). Ta kwota zostanie pomniejszona o obowiązkowe transfery na rzecz instrumentów i programów wdrażanych przez Komisję Europejską (KE) i na pomoc techniczną według koncepcji KE. Wyniosą one $2951 \mathrm{mln}$ euro (ponad $13337 \mathrm{mln}$ złotych). Wynika $z$ tego, że alokacja dla Polski po transferach wyniesie $61446 \mathrm{mln}$ euro (ponad $277705 \mathrm{mln}$ złotych) (Ministerstwo Inwestycji i Rozwoju, 2019, s. 41). Oznacza to, że w tej perspektywie Polska otrzyma mniejsze dofinansowanie niż w obecnie kończącej się oraz w poprzedniej.

\section{Zakończenie}

Budżet od perspektywy finansowej różni się głównie tym, że jest sporządzany na jeden rok, a perspektywa na dłuższy okres. Różnica polega również na planowaniu wydatków. W perspektywie finansowej są one uwzględnianie tylko w odniesieniu do głównych grup, a w budżecie muszą być podane szczegółowo.

W przeszłości Polska uczestniczyła w perspektywie 2000-2006, z której otrzymywała dotacje od 2004 roku, czyli od czasu akcesji do UE. Państwo to, w ramach tego wsparcia, otrzymało około 12,8 mld euro, czyli orientacyjnie 57,94 mld złotych. W tych latach były inne programy operacyjne, przykładowo:

- Zintegrowany Program Operacyjny Rozwoju Regionalnego, w ramach którego otrzymano $z$ Europejskiego Funduszu Rozwoju Regionalnego 2 530,4 mln euro, a z Europejskiego Funduszu Społecznego 438,4 mln euro (ponad $1984,86 \mathrm{mln}$ złotych);

- Sektorowy Program Operacyjny Rozwój Zasobów Ludzkich, dzięki któremu dotacje wyniosły 1 470,0 mln euro (ok. 2 127,93 mln złotych);

- Sektorowy Program Operacyjny Wzrost Konkurencyjności Przedsiębiorstw, w ramach którego wsparcie wyniosło 1 251,1 mln euro (ok. $5664,36 \mathrm{mln}$ złotych);

- Sektorowy Program Operacyjny Transport, dzięki któremu otrzymano 1 163,4 mln euro (ponad 5 267,29 mln złotych);

- Sektorowy Program Operacyjny Rybołówstwo i przetwórstwo ryb, dzięki któremu otrzymano dofinansowanie na poziomie 201,8 $\mathrm{mln}$ euro (ponad 913,65 mln złotych);

- Program Operacyjny Pomoc Techniczna, w ramach którego wsparcie wyniosło ok. 28,3 mln euro (ok. 128,13 mln złotych);

- Sektorowy Program Operacyjny Restrukturyzacja i Modernizacja Sektora Żywnościowego oraz Rozwój Obszarów Wiejskich, w ramach którego otrzymano 1 192,7 mln euro (ponad 5 399,95 $\mathrm{mln}$ złotych) (Portal Funduszy Europejskich, 2020).

Akcesja Polski do UE była jednym z najważniejszych wydarzeń najnowszej historii dla Polaków. Dzięki temu, że Polska należy do wymienionej organizacji, otrzymuje bardzo dużą pomoc finansową $w$ ramach różnych programów operacyjnych. Jak wynika z przeprowadzonej analizy, zwiększył się poziom pomocy porównując perspektywy finansowe 2007-2013 i 2014-2020. Jednak w przyszłym wsparciu na lata 2021-2027 dofinansowanie zmaleje $\mathrm{w}$ porównaniu $\mathrm{z}$ obydwoma poprzednimi perspektywami. 


\section{Bibliografia}

Janiak, K. (2015). Budżet Unii Europejskiej. Warszawa: Ministerstwo Spraw Zagranicznych.

Kabat, D., i Rudnicki, Z. (2009). Studia Europejskie w Polsce: początki i zmiany po pierwszych pięciu latach członkostwa w Unii Europejskiej. W: S. Konopacki (red.). Polska pięć lat w Unii Europejskiej. Łódź: Ibidem.

Komisja Europejska. (2020). Programy. Pobrane 07.07.2020 z https://ec.europa.eu.

Małuszyńska, E. (2018). Budżet Unii Europejskiej. W: E. Małuszyńska, i B. Gruchman (red.), Kompendium wiedzy o Unii Europejskiej. Warszawa: PWN.

Ministerstwo Inwestycji i Rozwoju. (2019). Założenia do umowy partnerstwa na lata 2021-2027. Pobrane 07.07.2020 $\mathrm{z}$ https://www.funduszeeuropejskie.gov.pl.

Musiałkowska, I. (2009). Wykorzystanie Funduszy strukturalnych w Polsce po 2004 roku. W: S. Konopacki (red.). Polska pięć lat w Unii Europejskiej. Łódź: Ibidem.

Oręziak, L. (2009). Finanse Unii Europejskiej. Warszawa: PWN.

Perkowski, M. (2013). Dalsze możliwości korzystania przez państwa członkowskie UE ze środków funduszy europejskich oraz środków wynikających $z$ inicjatyw unijnych oraz stosowania instrumentów i mechanizmów finansowych UE. W: Kosikowski C. (red.), Przyszłość Unii Europejskiej w świetle jej ustroju walutowego ifinansowego. Białystok: Temida 2.
Portal Funduszy Europejskich. (2020). Pobrane 07.07.2020 z https://www.funduszeeuropejskie.gov.pl.

Szymańska, A. (2008). Fundusze unijne i europejskie 2007-2013 dla samorzadu terytorialnego. Warszawa: Placet.

Tkaczyński, J.W., Willa, R., i Świstak, M. (2008). Fundusze Unii Europejskiej 2007-2013: cele, dziatania, środki. Kraków: Uniwersytet Jagielloński.

Tomaszkiewicz, B. (2014). Pieniądze z Unii Europejskiej 2014-2020: nowe zasady finansowania. Warszawa: Infor Biznes.

Zdanukiewicz, J. (2012). Regionalne programy operacyjne. W: E. Kornberger-Sokołowska (red.), Jednostki samorządu terytorialnego jako beneficjenci środków europejskich. Warszawa: Wolters Kulwer Polska.

Informacje uzupełniające

Wkład autorski: autor zaakceptował ostateczną wersję artykułu.

Źródła finansowania: artykuł został w całości sfinansowany ze środków własnych autora.

Podziękowania autorskie: autor składa podziękowania za pomoc w przygotowaniu artykułu następującym osobom: Paulina Pukin. 
Aneks

Tabela 1.

Porównanie programów krajowych i regionalnych oraz dofinansowania z UE w perspektywach na lata 20072013 i $2014-2020$

\begin{tabular}{|c|c|c|c|c|}
\hline \multicolumn{2}{|c|}{ Perspektywa 2007-2013 } & \multicolumn{2}{|c|}{ Perspektywa 2014-2020 } & \multirow{2}{*}{$\begin{array}{c}\text { Wzrost/spadek } \\
\text { dofinansowania } \\
(w \%)\end{array}$} \\
\hline program & $\begin{array}{l}\text { dofinansowanie } \\
\text { (w mld euro) }\end{array}$ & program & $\begin{array}{l}\text { dofinansowanie } \\
\text { (w mld euro) }\end{array}$ & \\
\hline Infrastruktura i Środowisko & 28,3 & Infrastruktura i Środowisko & 27,4 & -3 \\
\hline \multirow{2}{*}{ Innowacyjna Gospodarka } & \multirow{2}{*}{8,7} & Inteligentny Rozwój & 8,6 & \multirow{2}{*}{24} \\
\hline & & Polska Cyfrowa & 2,2 & \\
\hline Kapitał Ludzki & 10,0 & Wiedza Edukacja Rozwój & 4,7 & -53 \\
\hline Pomoc Techniczna & 0,5 & Pomoc Techniczna & 0,7 & 40 \\
\hline Rozwój Polski Wschodniej & 2,4 & Polska Wschodnia & 2,0 & -17 \\
\hline $\begin{array}{l}\text { szesnaście Regionalnych } \\
\text { Programów Operacyjnych }\end{array}$ & 17,3 & $\begin{array}{l}\text { szesnaście Regionalnych } \\
\text { Programów Operacyjnych }\end{array}$ & 31,2 & 80 \\
\hline razem & 67,2 & razem & 76,8 & 14 \\
\hline
\end{tabular}

Źródło: Opracowanie własne na podstawie Portal Funduszy Europejskich (2020).

Tabela 2 .

Porównanie pomocy finansowej z UE dla województw w ramach szesnastu Regionalnych Programów Operacyjnych w perspektywach na lata 2007-2013 oraz 2014-2020

\begin{tabular}{lccc}
\hline \multirow{2}{*}{ Województwo } & Perspektywa 2007-2013 & Perspektywa 2014-2020 & $\begin{array}{c}\text { Wzrost/spadek } \\
\text { dofinansowania (w \%) }\end{array}$ \\
\cline { 2 - 4 } dolnośląskie & 1,24 & 2,25 & 81 \\
kujawsko-pomorskie & 0,95 & 1,90 & 100 \\
lubelskie & 1,16 & 2,23 & 92 \\
lubuskie & 0,44 & 0,90 & 104 \\
tódzkie & 1,01 & 2,25 & 123 \\
małopolskie & 1,29 & 2,87 & 122 \\
mazowieckie & 1,83 & 2,08 & 114 \\
opolskie & 0,43 & 0,90 & 109 \\
podkarpackie & 1,13 & 2,10 & 86 \\
podlaskie & 0,64 & 1,21 & 89 \\
pomorskie & 0,89 & 1,86 & 109 \\
śląskie & 1,71 & 3,47 & 103 \\
świętokrzyskie & 0,73 & 1,36 & 86 \\
warmińsko-mazurskie & 1,03 & 1,72 & 67 \\
wielkopolskie & 1,27 & 2,45 & 93 \\
zachodniopomorskie & 0,84 & 1,60 & 90 \\
\hline
\end{tabular}

Źródło: Opracowanie własne na podstawie Komisja Europejska (2020) i Portal Funduszy Europejskich (2020). 
Comparison of support for Poland from the European Union under the 2007-2013 and 2014-2020 financing

\section{Abstract}

Motivation: There is a lot of information in the literature on this subject about the subsidies that Poland receives from the European Union (EU). However, there is a lack of information on the differences between the financial perspective and the budget and a comparison of support for Poland under different financial perspectives. There is a gap in the literature on the subject which should be filled.

Aim: The aim of the article is to indicate the differences between the financial perspective and the budget and to check whether financial support for Poland from the EU increases, comparing subsequent financial perspectives.

Materials and methods: The article uses literature on the subject, information on public statistics and comparative analysis tools.

Results: Some national programmes have been reshaped in the 2014-2020 perspective, but their priorities have not changed. The EU support for Poland and its individual voivodships has increased in the next perspective, but this does not mean that Poland gets bigger grants in each subsequent one.

Keywords: financial perspective; European Union; Poland; budget JEL: F02; O52; G28; R58 